\title{
EFEK PEMBERIAN $\alpha$-MANGOSTIN DARI GARCINIA TETRANDA PIERRE TERHADAP MORFOLOGI P.FALCIPARUM
}

\author{
Hadi Kuncoro \\ Kelompok Bidang Ilmu Bahan Alam Hayati, Fakultas Farmasi, Universitas Mulawarman, Samarinda \\ e-mail : kuncoro_hadi82@yahoo.com
}

\begin{abstract}
Morphological changes assay to $P$. falciparum from the effects of $\alpha$-mangostin from $G$. tetranda using TEM methods has been done. This test aims to determine the effect of mangostin on P. falciparum by observing morphological ultrastructure of $P$. falciparum using transmission electron microscope (TEM). $\alpha$-Mangostin known to cause morphological changes in ultrastructure of P.falciparum after contact with $\alpha$-mangostin on the 12 and 24 hour.
\end{abstract}

Key words: $\alpha$ - Mangostin, G. tetranda, P. falciparum, Transmission Electron microscope (TEM)

\begin{abstract}
ABSTRAK
Telah dilakukan pengujian terhadap perubahan morfologi $P$. falciparum akibat efek pemberian $\alpha$-mangostin dari G. tetranda menggunakan metode TEM. Pengujian ini bertujuan untuk mengetahui efek pemberian mangostin kepada $P$. falciparum dengan melakukan pengamatan ultrastruktur dari morfologi $P$. falciparum menggunakan Mikroskop Elektron transmisi (TEM). Diketahui $\alpha$-Mangostin menyebabkan perubahan morfologi pada ultrastruktur dari P.falciparum setelah pemberian $\alpha$-mangostin pada jam ke 12 dan 24 .
\end{abstract}

Kata Kunci: $\alpha$-Mangostin, G. tetranda, P. falciparum, Mikroskop Elektron Transmisi.

\section{PENDAHULUAN}

Garcinia merupakan salah satu genus yang tersebar luas diseluruh dunia, terutama didaratan rendah hutan hujan tropis Asia Tenggara maupun Afrika bagian barat. Tanaman yang merupakan keluarga dari Guttiferae ini digunakan secara umum sebagai obat tradisional dan diketahui kaya akan metabolit sekunder diantaranya biflavonoid, santon, dan isoprenil benzofenon. Senyawa yang banyak ditemukan dalam spesies Garcinia umumnya memberikan bioaktifitas, seperti antioksidan, sitotoksik, antibakteri, bahkan sebagai antimalaria. Salah satu spesies Garcinia yang belum banyak diteliti adalah Garcinia tetranda Pierre (wadung). Spesies ini banyak ditemui di daerah Indonesia Timur merupakan koleksi Taman Nasional Meru Betiri, Jember.

Berdasarkan hasil penelitian kelompok kimia tumbuhan ITS, G. tetranda Pierre dilaporkan mengandung senyawa santon, khususnya santon terprenilasi mulai dari monoprenilasi sampai triprenilasi. Bagianbagian tertentu dalam satu tumbuhan 
berpeluang menghasilkan senyawa yang sama atau berbeda. Jenis santon terprenilasi seperti $\alpha$-mangostin yang diisolasi dari kulit akar tanaman ini juga ditemukan dalam tumbuhan Garcinia mangostana dan dilaporkan aktivitasnya sebagai antimalaria [1]. Berdasarkan laporan penelitian terdahulu terhadap pengujian penghambatan pertumbuhan parasit Plasmodium falciparum secara in vitro terhadap delapan senyawa santon yang diisolasi dari tumbuhan Garcinia tetranda Pierre (Wadung), diketahui bahwa $\alpha$ mangostin memiliki nilai $\mathbf{I C}_{\mathbf{5 0}} \mathbf{0 , 5 . 1 0} \mathbf{S}^{-3} \boldsymbol{\mu M}$, nilai ini lebih kecil dibandingkan standar kloroquin difosfat yang memiliki nilai IC $\mathbf{I}_{\mathbf{5 0}}$ = 3. $\mathbf{1 0}^{-3} \boldsymbol{\mu} \mathbf{M}$, hal ini menunjukkan bahwa kedua senyawa tersebut sangat poten untuk ditindak lanjuti menjadi obat antimalaria baru [2].

Senyawa aktif antimalaria bersifat sebagai inhibitor pada proses degradasi hemoglobin, maka inhibitor akan menghambat proses yang terkait dengan pembentukan asam amino sebagai kebutuhan esensial bagi pertumbuhan parasit malaria. Begitu juga hambatan proses detoksifikasi heme, menyebabkan terjadinya penumpukan heme bebas pada vakuola makanan dan akan bersifat toksik sehingga melisis membran, mengakibatkan hemolisis dan menghambat aktivitas beberapa enzim. Hal ini berpengaruh pada metabolisme parasit dan menyebabkan kematian parasit [3].

Pada penelitian ini akan dilakukan pengamatan terhadap perubahan morfologi $P$. falciparum akibat pemberian $\alpha$ Mangostin dari $G$. tetranda dengan menggunakan Mikroskop Elektron Transmisi (TEM).

\section{METODE}

\section{Sampel dan Bahan}

Sampel penelitian yaitu senyawa aktif $\alpha$ mangostin yang diisolasi dari kulit batang wadung (Garcinia tetranda Pierre) berasal dari Taman Nasional Meru Betiri, Jember, Provinsi Jawa Timur. Parasit malaria $P$. falciparum, yaitu parasit malaria $P$. falciparum strain 3D7 berasal dari Institute Biologi Molekuler Eijkman, Jakarta. Bahan yang digunakan untuk pembiakan parasit dan pengamatan ultrastruktur parasit yaitu $\mathrm{NaCl}$ (Merck), RPMI 1640, HEPES buffer, $\mathrm{NaHCO}_{3}$, hypoxanthine (Merck), Dsorbitol (Sigma), gentamisin sulfat (Sigma), serum dan sel darah manusia, aquadest steril for irrigation (Otsuka), larutan pewarna giemsa, minyak imersi. Isolat beku P.falciparum strain 3D7, glutaraldehid $5 \%$, natrium cacodilat $0,1 \mathrm{M}$, sukrosa 3\%, osmium tetraoksida $2 \%$ dan $\mathrm{K}_{3} \mathrm{Fe}(\mathrm{CN})_{6} \quad 2,5 \%$ dalam dapar Natrium cacodilat ditambahkan sukrosa $3 \%$, propilenoksida, spurr's mixture, uranil asetat $0,8 \%$, triple lead citrate.

\section{Instrumen}

Instrumen yang digunakan adalah Blue tip, yellow tip, culture tube, autoclaf, oven, botol laborat (Scott-Duran), tabung sentrifuse bertutup 15 dan $50 \mathrm{~mL}$ (Falcon), pipet mikro (Soccorex dan Ependorf), pinset, lampu spiritus, Laminar Air Flow (LAF/clean bench), mikroskop (Olympus $\mathrm{CH}-20)$, gelas obyek, lempeng mikro (microplate), petridish, Lempeng multi titer datar dengan 6 lubang (well), sentrifuge, alat ultrathin, pisau diamond, grid yang telah dilapisi formvar 5\%, Mikroskop Elektron Transmisi (TEM) JEOL 1010. 


\section{Pengamatan morfologi P.falciparum menggunakan TEM}

Uji senyawa aktif antimalaria pada morfologi vakuola makanan parasit malaria, yang diamati dengan Mikroskop Elektron Transmisi (TEM), dilakukan secara in vitro. Pengujian dilakukan menggunakan $P$. falciparum strain 3D7 pada lempeng multi titer datar dengan 6 lubang (well) meggunakan kultur parasit dengan tingkat parasitemia $1 \%$ dan hematokrit $5 \%$. Pengamatan ultrastruktur parasit dilakukan pada masa inkubasi 12 dan 24 jam dengan mengamati dibawah mikroskop elektron Transmisi (TEM) JEOL 1010. Pengujian senyawa aktif terhadap biakan P.falciparum dilakukan berdasarkan prosedur pengamatan Aikawa, 1971; Bozzola and Russel, 1998

\section{HASIL DAN PEMBAHASAN}

Pengamatan morfologi parasit malaria dengan menggunakan mikroskop elektron transmisi menunjukkan adanya perubahan morfologi parasit pada pengamatan 12 dan 24 jam. Bentuk parasit yang bulat dengan inti yang jelas dan diliputi oleh membran ganda banyak ditemukan pada pengamatan 12 jam pertama (Gambar 1.(a)). Parasit dan eritrosit dibatasi, yang umumnya berhimpit dengan membran luar parasit, sehingga tidak kelihatan dengan jelas. Pada membran luar parasit, kadang dapat ditemukan suatu lekukan, yang disebut sebagai sitostoma, yang memiliki fungsi sebagai mulut untuk mengisap hemoglobin, melalui proses endocytosis, yang melibatkan lisosom sekunder. Setelah proses endocytosis selesai, hemoglobin yang telah diperoleh akan diangkut oleh lisosom sekunder ke vakuola makanan melalui proses fusi (penggabungan). Pada tahap se-lanjutnya, parasit akan mencerna hemoglobin dan menghasilkan suatu hasil antara berupa heme, yang oleh parasit akan dipolimerasasi menjadi bentuk hemozoin. Sitoplama parasit dipenuhi oleh strukturstruktur seperti vakuola makanan dengan hemozoin yang berbentuk anyaman seperti tikar, organel yang memiliki membran ganda (bilaminar wall). Pada pengamatan di jam ke 24, parasit yang ditemukan umumnya dalam bentuk trofozoit tua, dengan struktur yang telah berkembang, misalnya inti yang berlobus, sitoplasma yang diliputi oleh berbagai organel, seperti vesikel transpor, vakuola makanan yang berisi hemozoin, badan osmiofilik serta sitostoma (Gambar 1.b.).

Hasil pengamatan ultra-struktur yang terkait dengan analisis morfologi parasit malaria (Gambar 1.), digunakan juga untuk meng-konfirmasi aktivitas biokimiawi senyawa santon terprenilasi aktif antimalaria dari kulit batang G. tetranda Pierre pada vakuola makanan parasit. Pengamatan ultrastruktur parasit malaria yang telah diinkubasi dengan senyawa aktif pada proses degradasi hemoglobin menjadi heme dan globin yang terjadi di vakuola makanan parasit malaria $P$. falciparum.

Berdasarkan Gambar 1, pada kontrol negatif (tanpa pemberian bahan aktif) selama inkubasi 12 dan 24 jam, terlihat ultrastruktur dari stadium trofozoit normal, dengan vakuola makanan berisi hemozoin dan terlihat vakuola makanan dalam bentuk normal (Gambar 1. (a) dan (b)). Adanya hemozoin pada vakuola makanan berarti bahwa proses pengambilan hemoglobin sebagai sumber nutrisi dibawa ke vakuola makanan dan telah diubah secara proteolisis menjadi heme dan globin. Selanjutnya heme yang bersifat toksik bagi parasit telah didetoksifikasi menjadi hemozoin (proses detoksifikasi berlangsung nomal), sedangkan globin akan terhidrolisis menjadi asam-asam amino yang digunakan parasit untuk melakukan sintesis protein. 
Hal yang berbeda teramati pada stadium trofozoit P.falciparum yang diinkubasi dengan senyawa $\alpha$-mangostin selama 12 dan 24 jam (Gambar 1.(c) dan (d)).
Mikrograf morfologi P.falciparum yang diinkubasi dengan senyawa aktif antimalaria pada 12 dan 24 jam, terlihat pada Gambar 1.

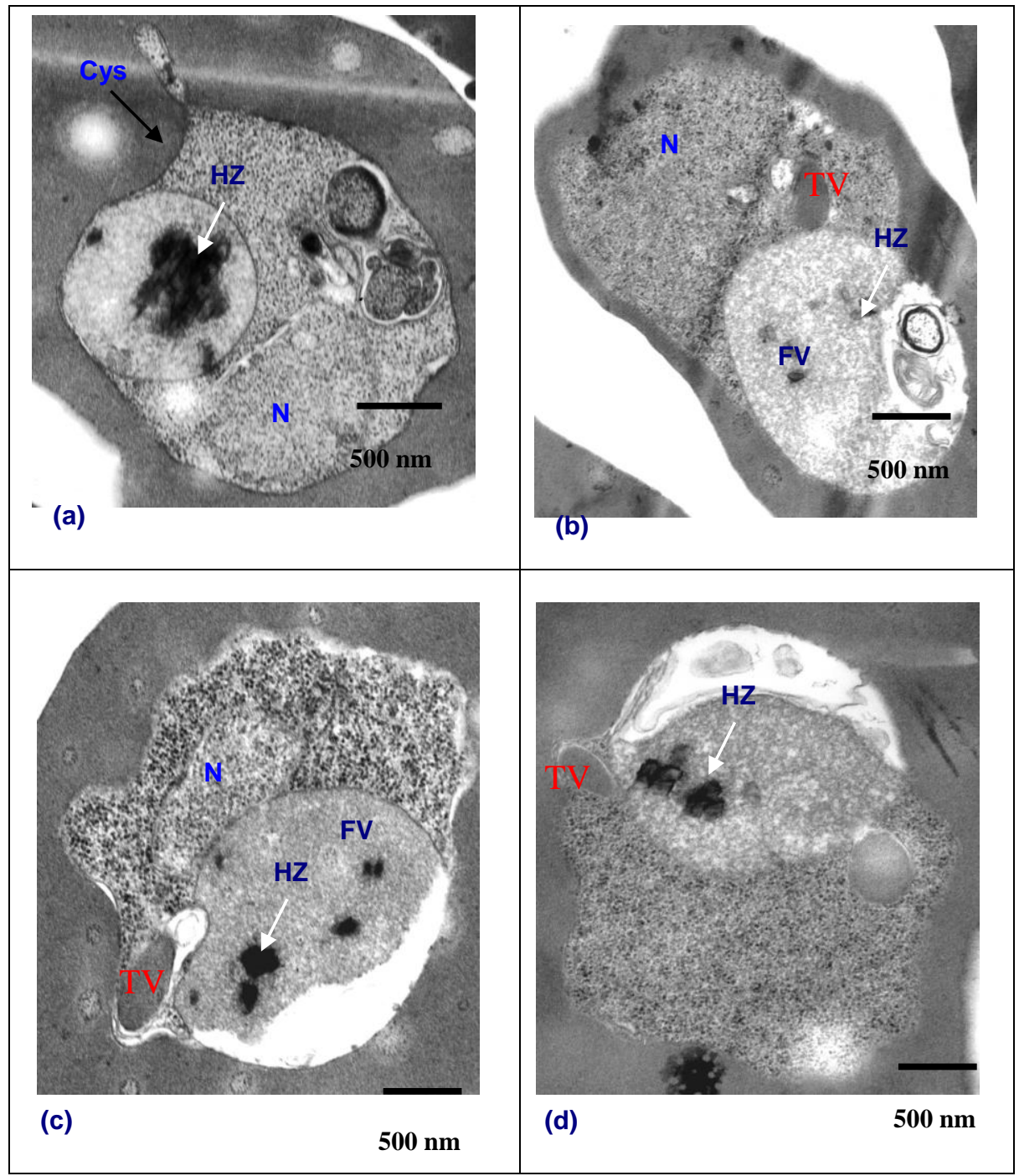

Gambar 1. (a-b) Trofozoit normal P. falciparum (kontrol negatif). P. falciparum yang diinkubasi 12 dan 24 jam dengan senyawa $\alpha$-Mangostin $(c-d)$, Pengamatan dengan mikroskop elektron transmisi pembesaran 15.000x. Skala dalam bar : $500 \mathrm{~nm}(\mathrm{a}-\mathrm{f}) . \mathrm{N}=$ nukleus, $\mathrm{Hz}=$ hemozoin, $\mathrm{TV}=$ transfer vesikel, Ery =eritrosit, Cys = sitostoma .

Hasil pengamatan ultrastruktur yang terkait dengan analisis morfologi parasit malaria (Gambar 1.), digunakan juga untuk mengkonfirmasi perubahan morfologi senyawa santon terprenilasi yang aktif sebagai antimalaria dari kulit batang $G$. tetranda pada vakuola makanan parasit. Pengamatan ultrastruktur parasit malaria yang telah diinkubasi dengan senyawa aktif pada hambatan proses degradasi 
hemoglobin didasarkan pada parameter pembengkakan vakuola makanan parasit akibat akumulasi globin pada vakuola makanan parasit malaria serta perubahan morfologi akibat pemberian senyawa aktif.

Berdasarkan Gambar 1., pada kontrol negatif (tanpa pemberian bahan aktif) selama inkubasi 12 dan 24 jam, terlihat ultrastruktur dari stadium trofozoit normal, dengan vakuola makanan berisi hemozoin (Gambar 1.(a) dan (b)). Adanya hemozoin pada vakuola makanan berarti bahwa proses pengambilan hemoglobin sebagai sumber nutrisi dibawa ke vakuola makanan dan telah diubah secara proteolisis menjadi heme dan globin. Selanjutnya heme yang bersifat toksik bagi parasit telah didetoksifikasi menjadi hemozoin (proses detoksifikasi berlangsung nomal). Hal yang sama teramati juga pada stadium trofozoit P.falciparum yang diinkubasi dengan senyawa $\alpha$-mangostin selama diinkubasi 12 dan 24 jam (Gambar 1.(c) dan (d).

Berdasarkan kajian ultrastruktur di atas maka, dapat diinterpretasikan bahwa senyawa $\alpha$-mangostin memiliki potensi untuk menghambat hidrolisis globin menjadi asam-asam amino parasit malaria selama masa inkubasi 24 jam.

\section{KESIMPULAN}

Berdasarkan pengujian yang dilakukan dapat disimpulkan bahwa mekanisme aksi $\alpha$-mangostin dari G. tetranda menyebabkan penghambatan hidrolisis globin menjadi asam-asam amino yang untuk kepentingan sintesis protein parasit P.falciparum menyebabkan kematian pada parasit.

\section{UCAPAN TERIMA KASIH}

Terima kasih kepada Fakultas Farmasi Universitas Airlangga, ITD Unair, FMIPA UB, Eijkman Institute, Jakarta. Dirjen Dikti sebagai sponsor dalam penelitian fundamental (2007) dan HPTP (2008 dan 2009). UP. Fakultas Farmasi Universitas Mulawarman.

\section{DAFTAR PUSTAKA}

1. Mahabusarakam, W.; Kuaha, K.; Wialirat, W.; \& Taylor, W.C. Prenylated Xanthones As Potential Antiplasmodial Substances, Planta Med, 2006; 72; 912-916

2. Ersam, T.; Santosa, M.; \& Widyawaruyanti, A. 2008, Kajian Bioaktivitas Dan Mekanisme Aksi Antimalaria Dari Senyawa Santon Pada Tumbuhan Wadung (Garcinia tetranda Pierre), Laporan Akhir Penelitian HPTP, LPPM-ITS; Surabaya

3. Sherman, I.W. 1998, Malaria, Parasite Biology, Pathogenesis and Protection, American Society for Microbiology Press; Washington, D.C., USA

4. Saxena, S.; Pant, N.; Jain, D.C.; \& Bhakuni, R.S. 2003, Antimalarial Agents from Plant Sources, Review Articles, Current Science Vol. 85 No. 9, November 10, hal 1314-1326

5. Rosenthal, P.J. 2002, Hydrolysis of Erythrocyte Proteins by Proteases of Malaria Parasites, Current Opinion in Hematology. Vol. 9, hal 140-145

6. Rosenthal, P.J.; Wollish, W.S.; Palmer, J.T.; \& Rasnick, D. 1991, Antimalarial Effects of Peptide Inhibitors of a Plamodium falciparum Cysteine Proteinase, Journal Clinical Investigation, Vol. 88, November, hal 14671472

7. Rosenthal, P.J. 1995, Plasmodium falciparum : Effects of Proteinase Inhibitors on Globin Hydrolysis by Cultured Malaria Parasites, Experimental Parasitology, Vol. 80, hal 272281

8. Kuncoro, H. 2010, Efek Pemberian $\alpha$ Mangostin Dan 1,3,6-Trihidroksi-7-Metoksi2(1,1-Dimetil-Metoksi-propena)-8-Prenilsanton Terhadap Plasmodium falciparum secara in vitro, Tesis, Fakultas Farmasi Universitas Airlangga, Surabaya 